\title{
The acquisition of pronouns by French children: A parallel study of production and comprehension
}

\author{
PASCAL ZESIGER, LAURENCE CHILLIER ZESIGER, \\ MARINA ARABATZI, and LARA BARANZINI \\ University of Geneva \\ STÉPHANY CRONEL-OHAYON \\ University Hospital of Lausanne
}

JULIE FRANCK and ULRICH HANS FRAUENFELDER

University of Geneva

CORNELIA HAMANN

University of Oldenburg

LUIGI RIZZI

University of Geneva and University of Siena

Received: June 27, 2008 Accepted for publication: April 18, 2009

\begin{abstract}
ADDRESS FOR CORRESPONDENCE
Pascal Zesiger, Faculté de Psychologie et des Sciences de l'Education, Université de Genève, 40

Boulevard du Pont d'Arve, Geneva 1205, Switzerland. E-mail: pascal.zesiger@unige.ch
\end{abstract}

\begin{abstract}
This study examines syntactic and morphological aspects of the production and comprehension of pronouns by 99 typically developing French-speaking children aged 3 years, 5 months to 6 years, 5 months. A fine structural analysis of subject, object, and reflexive clitics suggests that whereas the object clitic chain crosses the subject chain, the reflexive clitic chain is nested within it. We argue that this structural difference introduces differences in processing complexity, chain crossing being more complex than nesting. In support of this analysis, both production and comprehension experiments show that children have more difficulty with object than with reflexive clitics (with more omissions in production and more erroneous judgments in sentences involving Principle B in comprehension). Concerning the morphological aspect, French subject and object pronouns agree in gender with their referent. We report serious difficulties with pronoun gender both in production and comprehension in children around the age of 4 (with nearly $30 \%$ errors in production and chance level judgments in comprehension), which tend to disappear by age 6 . The distribution of errors further suggests that the masculine gender is processed as the default value. These findings provide further insights into the relationship between comprehension and production in the acquisition process.
\end{abstract}

(C) Cambridge University Press 2010 0142-7164/10 \$15.00 
The clitic system of Romance languages is of special interest for investigations of first language (L1) and second language (L2) acquisition and of language acquisition by children with specific language impairment (SLI) because of its particular grammatical properties. The syntax of Romance clitics involves diverse and complex properties such as dedicated positions in the functional structure of the sentence, movement processes, licensing, and locality constraints. In addition to the system of complement clitics typically found in Romance languages, French has a system of subject clitics, as well as a strong and a weak/clitic paradigm of pronouns with sharply different morphosyntactic properties. It is not surprising therefore that much recent work on the acquisition of French has focused on the pronominal system.

In this paper, we focus on two aspects of the production and comprehension of pronouns in French-speaking children: the grammatical nature of the pronouns (subject, object, and reflexive clitics) and their morphological properties (gender agreement).

\section{PRONOMINAL CLITICS IN ROMANCE LANGUAGES}

Romance pronominal clitics have several important properties. They cannot be used in isolation (Example 1, "a" refers to subject clitics and "b" to object clitics), cannot be conjoined (Example 2), cannot be modified (Example 3), generally cannot receive focal stress (Example 4), and usually cannot be separated from the verb (Example 5). Thus, their distribution is severely restricted compared to full nominal and pronominal expressions (for the original discussion of these properties, see Kayne, 1975).

1a. Qui est venu? ${ }^{*} \mathrm{Il}$

(who is come? He)

("Who came? Him")

2a. *Il et elle viendront

(he and she will come)

("he and she will come")

3a. *Ils deux viendront

(they two will come)

("They will both come/the two will come")

4a. * IL viendra (pas Marie)

(HE will come (not Mary))

("HE will come (not Mary)")

5a. *Il peut-être viendra

(he maybe will come)

("Maybe he will come") 1b. Qui as-tu vu? ${ }^{*}$ Le

(who have you seen? Him)

("Whom have you seen? Him")

2b. * Je le et la connais

(I him and her know)

("I know him and her")

3b. *Je les deux connais

(I them two know)

("I know them both.")

4b. * Je LE connais (pas Marie)

(I HIM know (not Mary))

("I know HIM (not Mary)")

5b. *Pierre le peut-être connaît

(Peter him maybe knows)

("Maybe Peter knows him")

Subject and object clitics differ structurally in at least two major properties. First, subject clitics occur in the canonical subject-verb (SV) order in that they (immediately) precede the inflected verb, as normal subjects generally do. Object clitics clearly occupy a special position in the inflectional field, distinct from 
the canonical object position to the right of the verb. According to the classical transformational analysis (Kayne, 1975), they are moved from the thematic object position (postverbal) to a preverbal position in the inflectional field, thus yielding a special object-verb (OV) order (Jean voit Pierre, Jean le voit). Other analyses that involve base generation of the clitic in a clitic position (e.g., Sportiche, 1998) still assume that the clitic is chainlinked to the thematic object position in the verb phrase (VP). Under our assumptions and those of others (see De Cat, 2005), subjects (clitic and nonclitic) are also moved from a VP-internal thematic position to the surface subject position (the highest specifier in the inflectional field), but this does not affect the canonical SV order. Putting together the VP-internal subject hypothesis and the derived position of object clitics, we reach the conclusion that sentences with object clitics always involve representations in which the subject and object chains cross each other (see Example 6b), a factor of complexity that may affect children's use of object clitics. It is important that no such crossing occurs in English in which the object pronoun does not move to a preverbal position.

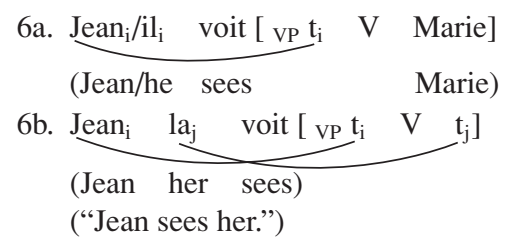

A similar argument was made by Fox and Grodzinsky (1998), who provided independent evidence that crossed subject and object chains are problematic for children. In their study of the comprehension of passive constructions by English children, the authors observed that although children had no difficulty with passive sentences involving actional verbs and a by-phrase (as in Examples 7a and b), they failed in their comprehension of passives involving nonactional verbs and a byphrase. In contrast, no difficulty was found with nonactional truncated passives (Example 7c).

7a. The rock star is being chased by the koala bear

7b. The boy is seen by the horse

7c. The bear is seen

The authors suggested that by-phrases with nonactional verbs require the transmission of the thematic role of the external argument (experiencer in Example 7b), intercepted by the passive mophology -en, to the by-phrase. This kind of thematic chain crosses the chain created by the movement of the object to subject position, similarly to the crossing we assume for anaphoric clitics:

8. the boy is see-en $_{j} \quad t_{i}$ by the horse ${ }_{j}$

Actional passives may involve direct default assignment of the agent role by the preposition by, without thematic transmission. Truncated nonactional passives also do not involve thematic transmission: the external role is intercepted by -en, and stays there:

9. the boy ${ }_{i}$ is see-en $t_{i}$ 
Zesiger et al.: Acquisition of French pronouns in children

The authors thus identify the difficulty that children experience with nonactional full passives in the crossing configuration that arises in Example 8, but does not in the other cases. In processing terms, retrieving an antecedent in a crossing chains configuration (Antecedent 1 Antecedent 2 Gap1 Gap2) involves additional memory load with respect to only nested dependencies. This may explain why the nonactional full passives and object clitics show a slower development.

Second, subject and object clitics also differ in categorial status. Subject clitics in standard and colloquial French are weak pronouns, that is, full determiner phrases (DPs) restricted to occur in a designated specifier position (Cardinaletti \& Starke, 1999). In contrast, object clitics are heads (presumably of Category $\mathrm{D}$, determiner), which get syntactically attached to other heads in the inflectional system.

Object clitics therefore have a special status compared to subject clitics: they always give rise to crossed chains, ${ }^{1}$ and they are heads. Following the logic of Cardinaletti and Starke (1999), in the normal case a head projects a full phrase, so that a "deficient" head failing to project has a special, marked status, which may be reflected by a delay in acquisition. To disentangle the respective role of these two factors in the acquisition of the pronominal system, we need to look at the acquisition of a system that dissociates the two factors. Under a well-motivated formal analysis, the system of reflexive clitics in standard French provides such a test case. ${ }^{2}$ Object and reflexive clitics look similar at first glance: Jean le voit, Jean se voit ("John sees him," "John sees himself"). Under classical analyses of Romance cliticization (from Kayne, 1975, on), the two constructions are fully parallel, with the clitic moved from object position, except for the status of the clitic, being a reflexive in one case and a pronoun in the other. However, the phenomenon of auxiliary selection casts doubts on a full assimilation of the two types of clitics and suggests that they involve quite different constructions. Whereas the object clitics take the auxiliary avoir (to have, as in Example 10a), the reflexive clitic takes être (to be, as in Example 10b).

10a. Jean l'a vu

(John him has seen)

("John has seen him.")

10b. Jean s'est vu

(John himself is seen)

("John has seen himself.")

Burzio (1986) suggests that reflexive clitic constructions are unaccusative-like, an approach directly supported by the auxiliary shift avoir $\rightarrow$ être. In this analysis, $s e$ is a marker of unaccusativity, which relates to the external argument, and thus has subjectlike status in absorbing the subject theta role (see Cocchi, 1995, for an adaptation of Burzio's analysis within the general theory of auxiliary selection proposed by Kayne, 1993).

Se clearly is a head, so this marked feature is common to reflexive and (accusative) object clitics. However, under this analysis, se corresponds to the external argument and the object is moved to subject position, as in an unaccusative structure. Therefore, reflexive clitic constructions involve nested chains of 
Zesiger et al.: Acquisition of French pronouns in children

Table 1. Distribution of the two marked properties (head status and chain crossing) in different linguistic constructions

\begin{tabular}{lcc}
\hline \hline \multicolumn{1}{c}{ Construction } & Head Status & Chain Crossing \\
\hline Subject clitics (Standard French) & - & - \\
Object clitics & + & + \\
Reflexive clitic & + & - \\
\hline \hline
\end{tabular}

subjects and objects, as in Example 11, with no crossing, in contrast to object clitic constructions.

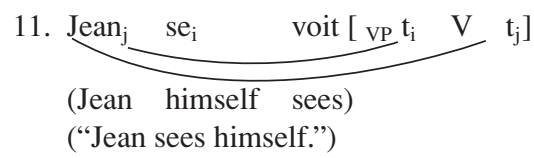

The properties of the three clitics are summarized in Table 1.

\section{SYNTACTIC CONSTRAINTS IN PRODUCTION AND COMPREHENSION}

The structural analysis of clitics provided in the previous section is typically an analysis of their derivation, that is, of the movement and chains involved in sentence formation. Hence, it has direct consequences on the way we conceive sentence production and its development. However, the same structure of movement and chains also needs to be processed in sentence comprehension. In other words, movement chains involved in object and reflexive clitics need to be processed when these elements are produced and when they are interpreted.

Generative syntax has developed a considerably elaborate framework to account for the interpretation of pronouns and reflexives, referred to as binding theory (Chomsky, 1981). The binding principles formulate the constraints on interpretation given in Example 12. ${ }^{3}$

12a. Principle A: An anaphor/reflexive is bound in its local domain

12b. Principle B: A pronoun is free in its local domain

In other words, a reflexive must find its antecedent within its immediate clause and is bound by this antecedent (through coindexation), that is, receives the same reference, whereas pronouns cannot have an antecedent in their immediate clause (must be contraindexed) and thus can be called "free' in their reference. For example, in Example 13a himself must refer to John, whereas in Example 13b him cannot refer to John.

13a. John $_{\mathrm{i}}$ tickled himself ${ }_{\mathrm{i}} /{ }^{*}$ himself $_{\mathrm{j}}$

13b. John $_{\mathrm{i}}$ tickled him ${ }_{\mathrm{j}}^{*}$ him $_{\mathrm{i}}$ 
Zesiger et al.: Acquisition of French pronouns in children

The same restrictions obtain for French clitic pronouns and reflexives, illustrated in Example 14 (see Zribi-Hertz, 1994).

14a. $\mathrm{Jean}_{\mathrm{i}} \mathrm{se}_{\mathrm{i}} /{ }^{*} \mathrm{se}_{\mathrm{j}}$ chatouillait

14b. $\mathrm{Jean}_{\mathrm{i}} \mathrm{le}_{\mathrm{j}} /{ }^{*} \mathrm{le}_{\mathrm{i}}$ chatouillait

Whereas binding relations refer to the links between a pronoun/anaphor and its antecedent, chain relations refer to the links between a moved element and its trace. It is however possible that chain configuration influences the processing of binding. More precisely, the crossing of subject and object chains involved in the derivation of object clitics may render the application of Principle B somewhat more difficult than the application of Principle A, whose interpretation only requires the processing of nested chains. Note that the major developmental problem observed in Principle B contexts in English has been shown to be because of an independent factor-coreference-that is pragmatic in nature (see next section) and that is not normally relevant for pronominal clitics. This was demonstrated by Chien and Wexler (1990), who reported that English children do not have difficulties in contexts where this pragmatic factor is neutralized such as pronouns with quantified antecedents for which coreference cannot be established (e.g., Every bear tickled him). ${ }^{4}$ As to Romance clitics, it has been argued that this pragmatic factor does not play a role, or plays a role only in very restricted contexts (Avrutin \& Wexler, 1992; Baauw \& Cuetos, 2003; Conroy, Takahashi, Lidz, \& Phillips, 2010; Hamann, 2002). Thus, the complexity effect found in the interpretation of pronominal clitics in French should be distinct in amplitude and in developmental timing from the pragmatic effect found in English.

\section{ACQUISITION OF CLITICS IN ROMANCE LANGUAGES}

Studies of both spontaneous and elicited production have shown that pronominal object clitics are commonly absent from the first utterances produced by French- (and Italian-) speaking children, in contrast with the regular production of pronominal subject clitics (Bottari, Cipriani, \& Chilosi, 1997; Friedemann, 1992; Hamann, Rizzi, \& Frauenfelder, 1996; Jakubowicz, Müller, Riemer, \& Rigaut, 1997; Jakubowicz \& Rigaut, 2000; Pierce, 1992). Moreover, this difficulty with object clitics is found not only in L1 acquisition but also in young L2 learners of French (White, 1996) and in children with SLI (Chillier et al., 2001; Hamann et al., 2003; Jakubowicz, Nash, Rigaut, \& Gérard, 1998; Paradis, Crago, \& Genesee, 2003). With respect to reflexive clitics, studies of spontaneous production reported a profile similar to the one observed for object clitics (Hamann, Rizzi, \& Frauenfelder, 1996; Jakubowicz \& Rigaut, 2000). However, experimental studies of elicited production showed that children produce reflexive clitics significantly more than object clitics, although to a lesser extent than subject clitics (Jakubowicz, 1989; Jakubowicz et al., 1998; Jakubowicz \& Rigaut, 2000).

As for the comprehension of object clitics, expressed in terms of the sensitivity to the requirements of the Binding Theory, it appears to be good in French and 
Italian (Hamann, Kowalski, \& Philip, 1997; Jakubowicz, 1989; McKee, 1992). Likewise, good performance in the comprehension of reflexive clitics was reported (Jakubowicz et al., 1998). The literature on French usually concludes that children are equally sensitive to the binding requirements of pronominal and reflexive clitics, although the results are not fully consistent for very young children. Jakubowicz (1989) reported 96\% accuracy for reflexive clitics in her group of children aged 3 years, 0 months $(3 ; 0)$ to 3;5 (in contexts like Nounours dit que Kiki se brosse, "Teddy bear says that Kiki brushes himself") compared to nearly $80 \%$ accuracy for pronominal objet clitics (in contexts like Nounours dit que Kiki le brosse). Their more recent study (Jakubowicz et al., 1998) on older children (5;6 to $5 ; 11)$ did not show any significant difference between the two clitics, although the data suggest again a tendency toward better performance with the reflexive (86\% correct responses) than with the pronominal object clitic $(80 \%$ correct responses).

The finding of overall good performance on pronominal object clitics contrasts with the long interpretive delay shown by typically developing children speaking Germanic languages. Typically, in these languages, children allow the pronoun to be anaphorically linked to the nominal expression (e.g., in "Mama Bear tickles her" is interpreted as meaning that Mama bear tickles herself; Chien $\&$ Wexler, 1990). Similar errors in the interpretation of pronouns were observed in children of languages like Dutch, Icelandic, or Russian (Avrutin \& Wexler, 1992; Coopmans \& Philip, 1995; Koster, 1993; Sigursjónsdóttir \& Hyams, 1992). Learners of languages like French, Spanish, or Italian reject this anaphoric dependency. Hence, the crosslinguistic difference in acquisition must be because of the morphosyntactic status of pronouns in these two groups of languages: in Romance, pronouns are clitics, whereas in English (and the other languages from this group), they are not. In contrast to clitic pronouns, strong pronouns can be associated with emphatic stress or with a pointing gesture (Avrutin \& Wexler, 1992; McDaniel \& Maxfield, 1992). Such deictic use and other theoretical considerations have led to the assumption that pronouns receive reference through two different mechanisms, variable binding or coreference (Reinhart, 2004; Reuland, 2001), and that it is the latter that is difficult for children. Hence, the delay in Principle B in Germanic languages can be attributed not to a lack of syntactic competence, but to independent problems children may have with the identification of the referential properties of pronouns and their pragmatics. If, like in Romance languages, coreference is not an option for pronoun interpretation, then children should perform well in interpretation tasks.

In summary, acquisition studies consistently point to a systematic delay in the production of object clitics in French-speaking children (and more generally in children speaking Romance languages), which is not reported for subject or reflexive clitics. ${ }^{5}$ Moreover, crosslinguistic comparison suggests that the high rate of object pronoun omission is specific to Romance languages, given the much lower omission rate reported in children speaking Germanic languages (Bloom, 1990; Bloom, Baars, Conway, \& Nicol, 1994). In contrast, French-speaking children are generally good at interpreting the object pronoun (although very young children seem to show better performance with reflexives), in sharp contrast with what was found in the acquisition of Germanic languages. 
Zesiger et al.: Acquisition of French pronouns in children

\section{MORPHOLOGICAL CHARACTERISTICS OF CLITICS IN FRENCH}

Subject and object pronominal clitics express gender in their morphology (Examples $15 \mathrm{a}$ and $15 \mathrm{~b}$ ). The two pronominal clitics are also specified for number (Examples 15c and 15d), although the subject clitic only marks number in limited contexts in the spoken format (liaison is required when the clitic is followed by a vowel-initial verb, e.g., ils avaient, they had). In addition, the object clitic is also specified for case (i.e., accusative or dative), as illustrated in Example 15e. In contrast, the reflexive clitic does not carry any morphosyntactic specification (Example 15f) of number, gender, or case. Note that both pronominal and reflexive clitics are marked for person.

15a. Il/elle couvre la fille (He/she covers the girl)

15b. Le garçon le/la couvre (The boy him/her covers)

15c. Il/ils couvre(nt) la fille (He/they cover(s) the girl)

15d. Le garçon le/les couvre (The boy him-S/him-P covers)

15e. Le garçon le couvre/lui parle (The boy him-acc covers/him-dat talks to)

15f. Le garcon se couvre/La fille se couvre/les garçons se couvrent (The boy covers himself-M/The girl covers herself-F/ The boys cover themselves-P)

Studies of spontaneous production show that gender appears early on articles produced by French-speaking children, from the age of 2 (e.g., Kupisch, Müller, \& Cantone, 2002), before number and case (Rondal, Espéret, Gombert, Thibaut, \& Comblain, 1999). Experimental research also shows that gender errors on determiners are rare in the production of young children (see for a recent study Jakubowicz \& Nash, in press). Thus, gender as a lexicosyntactic property of the noun seems to be acquired as early as the noun appears in the child's lexicon.

However, gender does not seem to appear this early on pronouns. Studies on French by Jakubowicz and her colleagues consistently showed that, although young French children produce gender correctly on the determiner most of the time, this is not the case for subject and object pronouns (Jakubowicz, 1989; Jakubowicz et al., 1998; Jakubowicz \& Nash, in press). However, their work shows that gender is not produced randomly: most errors involve replacing the feminine clitic pronoun (elle/la) by the masculine clitic pronoun (il/le; see also Clark, 1985).

The role of gender in the process of sentence comprehension is less known. A study conducted on French-speaking children suggests that until the age of $6 ; 0$, they do not take into account the gender of the subject clitic to disambiguate attachment in the processing of pronoun-antecedent relationships (Kail \& Léveillé, 1977). The weak role of gender in sentence processing was further taken as an argument for the claim that gender appears in children's productions before it is used as a cue to sentence comprehension (in French, see Kail, 1989; in Italian, see Bates \& Devescovi, 1989). It is interesting that observations in other languages that have grammatical gender, like German and Icelandic, have suggested that young children are more accurate in selecting the right pronoun to refer to inanimate referents, whose gender is linguistically determined, than to animate referents, whose gender is determined by the biological sex of the referent, that is, extralinguistic information (Levy, 1988). 
In contrast to the weak role of gender observed in pronoun interpretation by children speaking Romance languages, a strong role was reported for Englishspeaking children. As mentioned in an earlier section, young English-speaking children typically show a delay of Principle B, allowing for incorrect coreference of the object pronoun with the local antecedent. However, Chien and Wexler (1990) observed that gender marking can considerably improve children's performance. In Example 16a the mismatching of gender features on the object pronoun and the local antecedent rules out coreference. Children from the age of 2;6 were found to perform nearly at ceiling in this condition, in contrast to Example 16b in which the delay of Principle B was typically observed.
16a. Snoopy says that Sarah should point to him
16b. Snoopy says that Adam should point to him

Hence, whereas English children use gender cues from early on, such cues do not seem to influence the performance of Romance-speaking children greatly when disambiguating pronoun interpretation.

\section{THE CURRENT STUDY}

This paper examines the production and comprehension of pronominal and reflexive clitics by typically developing French-speaking children. Their mastery of subject, object, and reflexive clitics is systematically investigated with two experimental techniques: elicited production and truth-value judgments. The elicitation task tests for the obligatory use of clitics that cannot be examined in spontaneous production. The truth-value judgment task was employed to determine all the possible readings that a child's grammar can assign to a given sentence, thereby not basing conclusions only on the preferred interpretation, as is the case for other comprehension tests (e.g., picture selection and act-out tasks).

The theoretical focus of the study is the acquisition of two core aspects of the French pronominal system: syntactic and morphological properties. With respect to syntactic factors, we suggested that French pronominal and reflexive clitics can be characterized in terms of two properties: their categorical status (head or specifier) and the chains of movement they involve (crossed or nested). If the critical feature in determining the delayed acquisition of object pronominal clitics is their head status, we would expect reflexive clitics to be delayed on a par with object clitics $(\mathrm{S}>\mathrm{R}=\mathrm{O}$ ). If the critical factor is the crossing of chains, we would expect performance on reflexive clitics to differ from that on object pronominal clitics, and pattern with subject clitics $(\mathrm{S}=\mathrm{R}>\mathrm{O})$. If both factors are critical and additive, we would expect that reflexives have an intermediate status $(\mathrm{S}>$ $\mathrm{R}>\mathrm{O}$ ).

The morphology of French object pronouns marks gender but reflexives do not. Hence, the three clitics differ with respect to their morphological marking, a difference that may influence the participants' behavior. Whereas the object clitic needs to respect both syntactic and morphological constraints, the reflexive clitic does not. It is therefore necessary to partial out these two factors in order to analyze syntactic performance independently of gender. However, gender acquisition is an important phenomenon that is very little understood. It gives rise to 
Zesiger et al.: Acquisition of French pronouns in children

potentially interesting crosslinguistic differences between French and English that require further investigation. This study systematically examines the acquisition of gender morphology on subject and object clitic pronouns in production and comprehension, and the use of gender markers on object clitics in comprehension.

\section{METHOD}

\section{Participants}

Ninety-nine French-speaking children with typical language development took part in the study. Ninety-four were fully monolingual, and the remaining 5 were clearly French dominant, with an exposure to L2 that was below $20 \%$ of time spent awake. ${ }^{6}$ They were selected from kindergarten and elementary classes in which the primary language of instruction was French. These 99 participants, whose age ranged from $3 ; 5$ to $6 ; 5$, were divided into five age groups with approximately the same number of girls and boys in each group: $4 ; 0(N=18$, mean $=4 ; 0$, range $=3 ; 5-4 ; 5), 4 ; 6(N=20$, mean $=4 ; 9$, range $=4 ; 6-4 ; 11), 5 ; 0(N=19$, mean $=5 ; 3$, range $=5 ; 0-5 ; 6), 5 ; 6(N=22$, mean $=5 ; 9$, range $=5 ; 7-5 ; 11)$, and $6 ; 0(N=20$, mean $=6 ; 3$, range $=6 ; 0-6 ; 5)$. We note that the mean age of the group corresponds within 3 months to the given age group. Fifteen children were excluded because they did not complete one of the experimental or control task (the sentence repetition task in most cases); 2 additional children had to be excluded because their dominance for French could not be firmly established.

Two control tasks were administered to all the participants, the Epreuve de Compréhension Syntaxico-Sémantique (E.CO.S.SE; Lecocq, 1996), a standardized test assessing sentence comprehension (French adaptation of the Test for Reception of Grammar; Bishop, 1983), and a sentence repetition task (Isadyle: A battery of language tests; Piérart, Comblain, Grégoire, Mousty, \& Noël, 2010). The children included in this study had language scores within the normal range for their chronological age.

\section{Materials and design}

Forty-eight photographs and their corresponding lead-in questions were used as experimental materials to elicit the three relevant types of clitics: subject clitics ( $i l$ "he," elle "she"), object clitics (le "him," la "her," les "them"), and the reflexive clitic se ("himself/herself"). The number was manipulated in the context of the object clitics only, because there are no audible differences between the singular ("il," "elle," "se") and plural ("ils," "elles," "se") forms of subject and reflexive clitics. These photographs depicted combinations of four people (a mother, a father, a boy, and a girl) performing six different activities (laver, mouiller, brosser, couvrir, réveiller, mesurer "wash," "wet," "brush," "cover," "wake up," "measure"). For example, one picture that showed a man covering a boy lying in a bed was accompanied by a lead-in question (e.g., "What is daddy doing to Pierre?"). Twenty-four of the 48 items were designed to elicit the masculine subject clitic and 24 the feminine subject clitic. For both of these 24 items, 6 were designed to elicit each of the three accusative clitic forms le, la, and les, and the 
reflexive clitic form se, respectively. Thus, all combinations of subject and object clitics were included in the fully counterbalanced design.

The experimental stimuli that were designed to test the comprehension of clitics_both object (le "him," la "her") and reflexive clitics (se "himself or herself")_-involved the same pictures as in the production experiment as well as accompanying sentences so that in every picture there were two characters. Examples of the 56 sentence-photograph pairs used in the truth-value judgment task are shown in Table 2 and the full list of stimuli is presented in Appendix A. Note that, unlike in the production task, the number was not manipulated in the comprehension task for the object clitics.

Twenty-eight of these sentences matched the picture perfectly (both syntax and morphology), but the other 28 sentences did not. Of these matching pairs, 16 sentences involved the binding Principle A, and 12 involved binding Principle B ([+syntax]). Moreover, 8 additional matching sentences that involved Principle B contained a clitic pronoun whose gender mismatched the sex of the local antecedent and the referential object ([-gender $]$ ).

In the $[-$ syntax] condition, the binding error could either be with respect to Principle B (eight sentences) or to Principle A (eight sentences). The eight sentences involving a Principle B mismatch were of two types: either with a clitic object that matched the sex of the local antecedent ([same gender]) or with a clitic that mismatched it ([different gender]). Finally, four sentence-photograph pairs were lexically incorrect such that the subject did not match the agent shown in the photograph. ${ }^{7}$

\section{Procedure}

All the children were tested individually in a quiet room of the school or kindergarten. Each child was seated at a table near two experimenters and completed all tests during two (or three for the youngest) 20- to 30-min sessions that were separated by 2 weeks at most. The order of the test administration was held constant across children. In order to avoid a learning effect across input sentences, the production of clitics (elicitation task) was tested before the comprehension of clitics (truth-value judgment task).

During the first session, the testing of all the participants began with the control tasks (sentence repetition and E.CO.S.SE), followed by the elicitation task. The first experimenter started the session by introducing a handpuppet that was learning to talk and initially, only listening, for example, during the control tasks.

For the elicitation task, the child was then invited to help the puppet improve its speech by answering its questions. The child was shown one photograph at a time, for example, a man covering (tucking in) a boy lying in a bed. After the first experimenter gave a short description of the picture (in the example, Il est tard, c'est l'heure d'aller au lit, il y a une couverture "It's late, it's time to go to bed, there is a bedcover"), the lead-in question was asked by the puppet (i.e., the second experimenter): Qu'est-ce que papa fait à Pierre? "What is daddy doing to Pierre?" In this example, the expected response was Il le couvre "He is covering him." The order of presentation of the items was held constant across participants. 
Table 2. Examples of sentence-photograph pairs in the experimental conditions of the truth-value judgment task

\begin{tabular}{|c|c|c|c|c|c|}
\hline & & & No. & Photograph & Sentence \\
\hline \multirow[t]{2}{*}{ +Syntax (match) } & Binding B & $\begin{array}{l}\text { +Gender } \\
\text {-Gender }\end{array}$ & $\begin{array}{r}16 \\
8\end{array}$ & $\begin{array}{l}\text { Dad is covering the boy } \\
\text { Dad is covering the boy }\end{array}$ & $\begin{array}{l}\text { Papa le couvre "Dad is covering him" } \\
\text { Papa la couvre "Dad is covering her" }\end{array}$ \\
\hline & Binding A & & 12 & $\begin{array}{l}\text { Dad is covering himself } \\
\text { The boy is looking on }\end{array}$ & Papa se couvre "Dad is covering himself" \\
\hline \multirow[t]{3}{*}{-Syntax (mismatch) } & Binding B & Same gender & 4 & $\begin{array}{l}\text { Dad is covering himself } \\
\text { The boy is looking on }\end{array}$ & Papa le couvre "Dad is covering him" \\
\hline & & Different gender & 4 & $\begin{array}{l}\text { Dad is covering himself } \\
\text { The boy is looking on }\end{array}$ & Papa la couvre "Dad is covering her" \\
\hline & Binding A & & 8 & Dad is covering the boy/girl & Papa se couvre "Dad is covering himself" \\
\hline -Lexical & & & 4 & $\begin{array}{l}\text { The boy is covering himself } \\
\text { Dad is looking on }\end{array}$ & Papa se couvre "Dad is covering himself" \\
\hline
\end{tabular}


The four people shown in the different photographs as well as the six verbs depicted ("wash," "wet," "brush," "cover," "wake up," and "measure") were initially introduced to the child. Before testing, four examples items were given with corrective feedback. The examiners did not start the task unless they were sure that the child understood the instructions. Administration of the experimental items took approximately $15 \mathrm{~min}$. The child responses were recorded on a minidisc and later transcribed. A simultaneous orthographic transcription was also made during testing by one of the examiners.

The second session involved the truth-value judgment task. The child was told that the puppet's speech had improved and that it would try at this point to describe the photographs. The child was presented one photograph at a time, for example, a man covering a boy lying in a bed. After the first examiner gave a short description presenting the activity and people in the photograph (in the example Il est tard, c'est l'heure d'aller au lit. Regarde, il y a la couverture. Voici papa et Pierre "It's late, it's time to go to bed. Look, there is the bedcover. Here are daddy and Pierre"), the puppet produced a sentence matching or not matching the photograph, and the child was invited to say whether the puppet had correctly described the picture or not. The order of presentation of the items was held constant across participants. Administration of the experimental items took approximately $20 \mathrm{~min}$. The child's responses were coded as correct or incorrect.

\section{Scoring and data analyses}

For the elicitation task, children's responses were scored according to three categories (examples of which are presented in Table 3):

[+Syntax]: When a syntactically correct clitic is produced, that is, when a subject, object, or reflexive clitic is produced when expected. This category is further divided into two subcategories, depending on whether the morphological features of the clitic (gender and number) are correct [+morphology] or not [-morphology]. Remember that in the elicitation task, the object clitic is marked for the two features, the subject clitic is marked for gender only, and the reflexive is unmarked.

[-Syntax]: When an error in the syntax of the clitic is produced. This category involves omissions (when the clitic is not produced) and substitutions (when a clitic of the incorrect category is produced, that is, a reflexive rather than an object or an object in place of a reflexive), or when the clitic is replaced by a strong pronoun (case).

Miscellaneous: This category involves lexicalizations, either correct or incorrect, and nontarget productions.

Analyses of variance (ANOVAs) were performed on those categories that conform to homogeneity and normality constraints of variance analyses (ANOVAs/multivariate ANOVAs [MANOVAs]). When appropriate, paired comparisons were carried out using Student $t$ tests. Given the presence of dichotomous responses and of ceiling effects in part of the data, we also used logistic regression with mixed effects using the method of Schall (1991), as implemented in S+6.2 (Insightful). This analysis is a generalization of a repeated-measure ANOVA to 
Zesiger et al.: Acquisition of French pronouns in children

Table 3. Examples of responses in the scoring categories of the elicitation task

\begin{tabular}{|c|c|c|}
\hline \multicolumn{3}{|c|}{ Subject } \\
\hline +Syntax & $\begin{array}{l}\text { +Morphology } \\
\text { - Morphology } \\
\text { Gender }\end{array}$ & $\begin{array}{l}\text { Il le lave (EXPECTED) } \\
\text { Elle le lave }\end{array}$ \\
\hline -Syntax & Omission & Le lave \\
\hline Miscellaneous & $\begin{array}{l}\text { Lexicalization } \\
\text { Nontarget }\end{array}$ & $\begin{array}{l}\text { Papa le lave } \\
\text { C'est laver }\end{array}$ \\
\hline \multicolumn{3}{|r|}{ Object } \\
\hline +Syntax & $\begin{array}{l}\text { +Morphology } \\
\text {-Morphology } \\
\text { Gender } \\
\text { Number }\end{array}$ & $\begin{array}{l}\text { Il le lave (EXPECTED) } \\
\text { Il la lave } \\
\text { Il les lave }\end{array}$ \\
\hline -Syntax & $\begin{array}{l}\text { Omission } \\
\text { Substitution } \\
\text { Case }\end{array}$ & $\begin{array}{l}\text { Il lave } \\
\text { Il se lave } \\
\text { Il lui lave }\end{array}$ \\
\hline Miscellaneous & $\begin{array}{l}\text { Lexicalization } \\
\text { Incorrect } \\
\quad \text { lexicalization } \\
\text { Nontarget forms }\end{array}$ & $\begin{array}{l}\text { Il lui lave le/son visage, il lave Pierre } \\
\text { Il le lave le/son visage, il leur lave le visage } \\
\text { C'est laver }\end{array}$ \\
\hline \multicolumn{3}{|c|}{ Reflexive } \\
\hline+ Syntax & +Morphology & Il se lave (EXPECTED) \\
\hline -Syntax & $\begin{array}{l}\text { Omission } \\
\text { Substitution }\end{array}$ & $\begin{array}{l}\text { Il lave } \\
\text { Il le lave }\end{array}$ \\
\hline Miscellaneous & $\begin{array}{l}\text { Lexicalization } \\
\text { Incorrect } \\
\quad \text { lexicalization } \\
\text { Nontarget }\end{array}$ & $\begin{array}{l}\text { Il lave son visage } \\
\text { Il lave la figure, il [Pierre] lave Pierre } \\
\text { C'est laver }\end{array}$ \\
\hline
\end{tabular}

data in which the dependent variable is a proportion (the number of trials is also included in the model). ${ }^{8}$ In these analyses, age (months) was entered as a continuous between-subject variable.

\section{RESULTS}

\section{Production}

The general distribution of responses to the elicitation task is presented in Table 4. 
Table 4. Mean percentages of responses in the scoring categories of the elicitation task

\begin{tabular}{|c|c|c|c|c|c|c|c|c|c|c|c|}
\hline & & \multicolumn{2}{|c|}{4 Years } & \multicolumn{2}{|c|}{ 4.5 Years } & \multicolumn{2}{|c|}{5 Years } & \multicolumn{2}{|c|}{ 5.5 Years } & \multicolumn{2}{|c|}{6 Years } \\
\hline & & Mean & $S D$ & Mean & $S D$ & Mean & $S D$ & Mean & $S D$ & Mean & $S D$ \\
\hline \multicolumn{12}{|c|}{ Subject } \\
\hline \multirow[t]{3}{*}{+ Syntax } & $\begin{array}{l}\text { +Morphology } \\
\text {-Morphology }\end{array}$ & 65.2 & 19.9 & 72.7 & 18.2 & 76.1 & 8.5 & 81.3 & 10.6 & 83.2 & 20.0 \\
\hline & Gender & 27.0 & 13.6 & 21.4 & 13.0 & 23.5 & 8.1 & 18.0 & 10.0 & 11.8 & 9.7 \\
\hline & Total & 92.2 & & 94.1 & & 99.6 & & 99.3 & & 95.0 & \\
\hline \multirow[t]{2}{*}{-Syntax } & Omission & 7.8 & 20.2 & 5.9 & 16.9 & 0.4 & 0.9 & 0.5 & 1.3 & 4.6 & 19.5 \\
\hline & Total & 7.8 & & 5.9 & & 0.4 & & 0.5 & & 4.6 & \\
\hline \multirow{3}{*}{ Miscellaneous } & Lexicalization & 0.0 & 0.0 & 0.0 & 0.0 & 0.0 & 0.0 & 0.2 & 0.9 & 0.4 & 1.1 \\
\hline & Nontarget & 0.0 & 0.0 & 0.0 & 0.0 & 0.0 & 0.0 & 0.1 & 0.4 & 0.0 & 0.0 \\
\hline & Total & 0.0 & & 0.0 & & 0.0 & & 0.3 & & 0.4 & \\
\hline \multicolumn{12}{|c|}{ Object } \\
\hline \multirow[t]{4}{*}{+ Syntax } & +Morphology & 45.6 & 34.9 & 69.4 & 21.8 & 64.5 & 18.6 & 76.9 & 22.1 & 76.4 & 23.3 \\
\hline & Gender & 7.0 & 6.3 & 9.3 & 7.9 & 10.8 & 8.4 & 8.2 & 5.7 & 7.8 & 8.3 \\
\hline & Number & 3.7 & 6.4 & 2.2 & 2.8 & 3.8 & 4.0 & 2.4 & 4.4 & 2.5 & 5.2 \\
\hline & Total & 56.3 & & 80.9 & & 79.1 & & 87.5 & & 86.7 & \\
\hline \multirow[t]{4}{*}{-Syntax } & Omission & 21.0 & 24.8 & 8.5 & 13.7 & 6.4 & 7.3 & 3.8 & 8.2 & 2.5 & 5.8 \\
\hline & Substitution & 3.1 & 7.5 & 0.6 & 1.5 & 0.4 & 1.0 & 2.5 & 10.1 & 0.1 & 0.6 \\
\hline & Case & 3.7 & 7.4 & 3.9 & 7.9 & 4.1 & 9.4 & 1.1 & 3.6 & 0.4 & 1.4 \\
\hline & Total & 27.8 & & 13.0 & & 10.9 & & 7.4 & & 3.0 & \\
\hline
\end{tabular}


Table 4 (cont.)

\begin{tabular}{|c|c|c|c|c|c|c|c|c|c|c|c|}
\hline \multirow[b]{2}{*}{ Subject } & & \multicolumn{2}{|c|}{4 Years } & \multicolumn{2}{|c|}{4.5 Years } & \multicolumn{2}{|c|}{5 Years } & \multicolumn{2}{|c|}{5.5 Years } & \multicolumn{2}{|c|}{6 Years } \\
\hline & & Mean & $S D$ & Mean & $S D$ & Mean & $S D$ & Mean & $S D$ & Mean & $S D$ \\
\hline \multicolumn{12}{|c|}{ Object } \\
\hline \multirow[t]{4}{*}{ Others } & $\begin{array}{l}\text { Lexicalization } \\
\text { Incorrect }\end{array}$ & 6.9 & 6.6 & 2.8 & 3.6 & 6.2 & 5.9 & 2.9 & 3.15 & 7.3 & 9.8 \\
\hline & lexicalization & 7.0 & 7.65 & 2.70 & 3.6 & 3.8 & 3.8 & 1.9 & 2.4 & 2.9 & 4.3 \\
\hline & Nontarget & 2.0 & 4.1 & 0.6 & 1.5 & 0.0 & 0.0 & 0.3 & 1.2 & 0.1 & 0.6 \\
\hline & Total & 15.9 & & 6.1 & & 10.0 & & 5.1 & & 10.3 & \\
\hline \multicolumn{12}{|c|}{ Reflexive } \\
\hline+ Syntax & +Morphology & 84.3 & 26.6 & 91.3 & 19.4 & 96.5 & 7.0 & 96.6 & 7.6 & 99.2 & 2.6 \\
\hline & Total & 84.3 & & 91.3 & & 96.5 & & 96.6 & & 99.2 & \\
\hline -Syntax & Omission & 8.8 & 17.0 & 4.6 & 10.6 & 2.2 & 4.7 & 0.8 & 2.5 & 0.4 & 1.9 \\
\hline & Substitution & 0.9 & 3.9 & 1.3 & 3.1 & 0.4 & 1.9 & 1.4 & 5.5 & 0.4 & 1.9 \\
\hline & Total & 9.7 & & 5.9 & & 2.6 & & 2.2 & & 0.8 & \\
\hline \multirow[t]{4}{*}{ Miscellaneous } & $\begin{array}{l}\text { Lexicalization } \\
\text { Incorrect }\end{array}$ & 0.9 & 2.7 & 2.4 & 9.4 & 0.4 & 1.9 & 0.8 & 2.5 & 0.0 & 0.0 \\
\hline & lexicalization & 1.9 & 7.9 & 0.4 & 1.9 & 0.0 & 0.0 & 0.4 & 1.8 & 0.0 & 0.0 \\
\hline & Nontarget & 3.2 & 8.6 & 0.0 & 0.0 & 0.5 & 1.9 & 0.0 & 0.0 & 0.0 & 0.0 \\
\hline & Total & 6.0 & & 2.8 & & 0.9 & & 1.2 & & 0.0 & \\
\hline
\end{tabular}


Zesiger et al.: Acquisition of French pronouns in children

\section{Syntactically correct responses [+ syntax]}

In our tasks, the three clitics differ with respect to the morphosyntactic information they have to express; gender, number, and case (i.e., accusative, dative) determine the form of object clitics; only gender determines the form of subject clitics (because number is not manipulated); but the reflexive is totally unmarked with respect to those features. Hence, in order to compare the three clitics at a strictly syntactic level, analyses were conducted on the overall percentage of responses in the $[+$ syntax $]$ category, that is, including morphosyntactically correct and incorrect responses ([+morphology] and [-morphology]). Logistic regressions were run with clitic type as a within-subject factor (subject, object, reflexive) and age as a between-subject factor. These analyses reveal an effect of age, $F(1,97)=18.78$, $p<.001$, that expresses the overall improvement as children get older, and an effect of clitic type, $F(2,194)=56.35, p<.001$. The analysis of the contrasts shows that there are more correct responses with subject and reflexive clitics than with object clitics, $t(194)=9.56, p<.001$, and $t(194)=4.85, p<.001$, respectively, whereas the rate of correct responses is comparable for subject and reflexive clitics, $t(194)=0.41, n s$. Even though this pattern is mainly observed in younger subjects because older ones tend to reach a ceiling effect, the Age $\times$ Clitic Type interaction does not reach significance, $F(2,194)=1.47, n s$, nor do any of the contrast interactions (all $p \mathrm{~s}>.10$ ).

Children show major difficulties in producing the correct gender both on the subject and the object pronouns that are still present at 6 years of age. Analyses were conducted on the proportion of gender errors with respect to the overall rate of pronouns produced in the [+syntax] category (eliminating the trials on which a plural form of the object clitic was expected). A MANOVA with age as a between-subjects factor and clitic type (subject vs. object) and gender (masculine vs. feminine) as within-subject factors was carried out. This analysis reveals a significant effect of age, $F(4,94)=4.43, p<.005$, indicating that gender errors decrease with age. The rate of gender errors is similar on subject and on object clitics (overall rate for subject $=21.2 \%$, overall rate for object $=18.6 \%), F(1$, $94)=1.25$, ns. Overall, gender errors are however more frequent with feminine $(28.1 \%)$ than with masculine pronouns $(11.7 \%)$, leading to a significant effect of gender, $F(1,94)=40.81, p<.001$. The masculine form is more often used instead of the feminine form than the opposite. There are less errors both on the masculine subject $(i l, 12.9 \%)$ and object $(l e, 10.4 \%)$ clitics than on the feminine subject (elle, 29.5\%) and object (la, 26.8\%) clitics. Finally, there are no significant interactions (all $F \mathrm{~s}<1.0$ ).

Errors of number or case on the singular object clitic were rather rare $(<5 \%)$. The plural target les was most often replaced by the singular masculine pronoun le than the opposite, showing that children tend to produce singular pronouns in plural contexts more often than the other way around (on average $93.1 \%$ of all number errors).

\section{Syntactically incorrect responses [-syntax]}

Omissions, constituting a major error pattern, were analyzed separately. Results of logistic regressions including age as a between-subject factor and clitic type 
Zesiger et al.: Acquisition of French pronouns in children

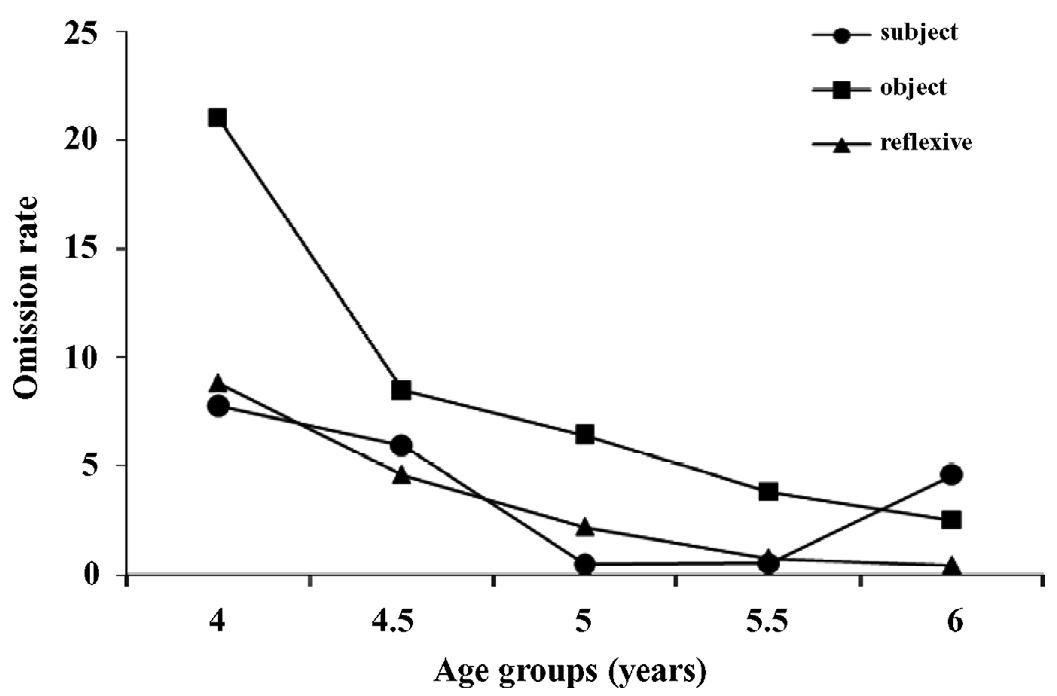

Figure 1. The results of the production task for the mean omission rate per age group for subject, object, and reflexive clitics.

as a within-subject factor indicate significant effects of age, $F(1,97)=21.03$, $p<.001$, and clitic type, $F(2,194)=14.38, p<.001$, as well as a significant interaction between the two factors, $F(2,194)=3.83, p<.025$. This interaction seems mainly because of the fact that, as can be seen in Figure 1, there is a high rate of object clitic omissions in the youngest group (21\%), which quickly drops below $10 \%$ from age $4 ; 6$ and continues to decrease until age $6 ; 0$ (2.5\%). By contrast, omissions of subject and reflexive clitics are rare and almost exclusively observed in the youngest groups.

Few cases of incorrect clitic category are observed. No errors were observed for subject clitics, but less than $3 \%$ errors were observed for object and reflexive clitics. There is a slight tendency for the children to make more errors with objects than reflexives, although this difference is impossible to estimate statistically.

\section{Miscellaneous}

Given the rather small number of errors in that category, we did not perform any statistical analyses on this category of responses. It is interesting to note, however, that lexicalizations represent $8.8 \%$ of the productions in the object contexts and, more generally, that incorrect lexicalizations decrease with age.

\section{Comprehension}

Binding. Table 5 displays the percentage of correct responses in the experimental conditions involving the manipulation of binding principles ( $\mathrm{A}$ and $\mathrm{B}$ ). As can be seen in this table, children are good at processing sentences involving binding 
Table 5. Mean percentages of correct responses in manipulations of binding principles in the truth-value judgment task

\begin{tabular}{|c|c|c|c|c|c|c|c|c|c|c|c|}
\hline & & \multicolumn{2}{|c|}{4 Years } & \multicolumn{2}{|c|}{ 4.5 Years } & \multicolumn{2}{|c|}{5 Years } & \multicolumn{2}{|c|}{ 5.5 Years } & \multicolumn{2}{|c|}{6 Years } \\
\hline & & Mean & $S D$ & Mean & $S D$ & Mean & $S D$ & Mean & $S D$ & Mean & $S D$ \\
\hline \multirow[t]{2}{*}{ +Syntax (match) } & Binding B & 95.5 & 5.2 & 97.2 & 6.2 & 98.0 & 4.7 & 97.7 & 4.1 & 98.4 & 2.8 \\
\hline & Binding A & 99.1 & 2.7 & 100.0 & 0.0 & 99.1 & 2.6 & 99.2 & 2.5 & 99.2 & 3.7 \\
\hline \multirow[t]{2}{*}{-Syntax (mismatch) } & Binding B & 87.5 & 21.0 & 86.3 & 16.7 & 95.4 & 8.5 & 91.5 & 20.2 & 93.8 & 14.9 \\
\hline & Binding A & 99.3 & 2.9 & 98.8 & 3.8 & 98.0 & 4.7 & 98.9 & 3.7 & 99.4 & 2.8 \\
\hline
\end{tabular}


Zesiger et al.: Acquisition of French pronouns in children

principles from the youngest age ( $>95 \%$ correct). They are generally better at processing syntactically appropriate sentences (i.e., to accept a sentence matching the photograph) than sentences involving a binding violation (i.e., not matching the photograph).

The results of the logistic regression analysis involving Principle (A vs. B) and Syntactic Appropriateness (syntactically appropriate [+] vs. inappropriate [-]) as within-subject factors and Age as a between-subject factor show that there is a significant difference between Principle A and Principle $\mathrm{B}, F(1,295)=$ 41.04, $p<.001$, with better performance with Principle A $(99.1 \%)$ than with Principle B (92.4\%). There is also a significant difference as a function of syntactic appropriateness, $F(1,295)=37.39, p<.001$ : syntactically appropriate sentences give rise to a higher proportion of correct responses $(98.3 \%)$ than inappropriate sentences $(94.9 \%)$. Finally, there is a significant Age effect, $F(1,97)=$ 4.46, $p<.05$. None of the other second, Principle $\times$ Syntactic Appropriateness: $F(1,292)=2.76, n s ;$ Age $\times$ Principle: $F(1,292)=1.35, n s ;$ Age $\times$ Syntactic Appropriateness: $F(1,292)=0.01, n s$; or third, Age $\times$ Principle $\times$ Syntactic Appropriateness: $F(1,291)=0.39, n s$, level interactions is significant.

Gender. The ease of processing sentences involving the syntax of binding contrasts with the difficulty children experience in processing the gender of the object pronoun. Table 6 displays the percentage of correct responses in the experimental conditions involving the manipulation of gender. Gender could only be manipulated in sentences involving Principle B, because the reflexive pronoun (Principle A) does not mark gender.

In sentences involving the appropriate expression of Principle B ([+syntax], i.e., when the action depicted on the photograph showed an agent acting on a patient), gender processing of the object clitic by young children is at chance level in this forced two-choice task (around 50\% mismatch detection until age 5;0) and only reaches about $75 \%$ error detection at age 6;0. However, there appears to be a difference between the masculine and the feminine clitics, with better performance to detect a gender error when the feminine clitic is used to refer to a male person, as illustrated in Table 7. A MANOVA involving morphological correctness type (correct $[+]$ vs. incorrect [-]) and gender (masculine vs. feminine) as within-subject factors and age as a between-subject factor confirms that there is a significant effect of gender, $F(1,94)=25,51, p<.001$, morphological correctness type, $F(1,94)=81.70, p<.001$, and age, $F(4,94)=2,70$, $p<.05$. There is also a significant interaction between gender and morphological correctness type, $F(1,94)=4,87, p<.05$. This is because there is almost no difference in the rate of correct responses between the masculine $(96.0 \%)$ and the feminine $(98.7 \%)$ pronouns in the gender match condition, whereas this difference is sizeable in the gender mismatch condition (57.8\% vs. $65.9 \%)$. None of the other second- and third-level interactions reaches significance.

Finally, it is interesting to note that children make more errors in conditions manipulating gender than in conditions that involve only same gender binding (overall $61.4 \%$ vs. $90.9 \%$ correct). This profile of performance appears to be the same across age groups. 
Table 6. Mean percentages of correct responses in manipulations of gender in the truth-value judgment task

\begin{tabular}{|c|c|c|c|c|c|c|c|c|c|c|c|c|}
\hline & & & \multicolumn{2}{|c|}{4 Years } & \multicolumn{2}{|c|}{ 4.5 Years } & \multicolumn{2}{|c|}{5 Years } & \multicolumn{2}{|c|}{ 5.5 Years } & \multicolumn{2}{|c|}{6 Years } \\
\hline & & & Mean & $S D$ & Mean & $S D$ & Mean & $S D$ & Mean & $S D$ & Mean & $S D$ \\
\hline \multirow[t]{2}{*}{+ Syntax (match) } & \multirow[t]{2}{*}{ Binding B } & +Gender & 95.5 & 5.2 & 97.2 & 6.2 & 98.0 & 4.7 & 97.7 & 4.1 & 98.4 & 2.8 \\
\hline & & -Gender & 47.2 & 40.6 & 50.0 & 40.8 & 63.2 & 39.2 & 70.5 & 34.4 & 76.3 & 33.9 \\
\hline \multirow[t]{2}{*}{-Syntax (mismatch) } & \multirow[t]{2}{*}{ Binding B } & Same gender & 84.7 & 22.9 & 81.3 & 19.7 & 94.7 & 10.5 & 93.2 & 15.8 & 93.8 & 13.8 \\
\hline & & Different gender & 90.3 & 21.2 & 91.3 & 20.3 & 96.1 & 9.4 & 89.8 & 26.3 & 93.8 & 17.9 \\
\hline
\end{tabular}


Zesiger et al.: Acquisition of French pronouns in children

Table 7. Mean percentages of correct responses with masculine and feminine object pronouns in conditions of gender match $([+$ Gender $])$ and gender mismatch ([-Gender])

\begin{tabular}{|c|c|c|c|c|c|c|c|c|c|c|}
\hline & \multicolumn{2}{|c|}{4 Years } & \multicolumn{2}{|c|}{ 4.5 Years } & \multicolumn{2}{|c|}{5 Years } & \multicolumn{2}{|c|}{ 5.5 Years } & \multicolumn{2}{|c|}{6 Years } \\
\hline & Mean & $S D$ & Mean & $\overline{S D}$ & Mean & $\overline{S D}$ & Mean & $S D$ & Mean & $S D$ \\
\hline \multicolumn{11}{|l|}{ +Gender } \\
\hline Masculine & 92.4 & 10.6 & 95.6 & 10.9 & 98.0 & 4.7 & 96.6 & 6.9 & 97.5 & 5.1 \\
\hline Feminine & 98.6 & 4.0 & 98.8 & 3.8 & 98.0 & 6.3 & 98.9 & 5.3 & 99.4 & 2.8 \\
\hline \multicolumn{11}{|l|}{-Gender } \\
\hline Masculine & 45.8 & 41.3 & 43.8 & 43.6 & 60.5 & 40.2 & 62.5 & 37.6 & 75.0 & 36.3 \\
\hline Feminine & 48.6 & 41.5 & 56.3 & 40.5 & 65.8 & 39.3 & 78.4 & 35.6 & 77.5 & 34.3 \\
\hline
\end{tabular}

\section{DISCUSSION}

The aim of this study was to examine the development of the pronominal system in a relatively large group of French-speaking children between 4 and 6 years old from the productive and the interpretive points of view. We chose to use an elicitation task and a truth-value judgment task, which have been proven to be fruitful methods.

Two questions guided our work. First, we asked whether the crossing of subject and object chains is responsible for the high rate of object pronoun omission traditionally reported in the productions of French-speaking children. If so, does this structural complexity also affect comprehension?

Second, we asked when and where gender marking on pronouns is correct in children's productions, and when it starts to influence their interpretation. These questions are important because proper gender assignment is an integral part of correct clitic production and comprehension in French.

\section{Acquisition of the syntax of pronominal and reflexive clitics}

Our major finding is that object clitics are problematic both in production and comprehension, giving rise to worse performance than reflexives and in production, than subject clitics. Analyses of the production of three types of clitics showed that subject and reflexive clitics were more often produced than object clitics even though subject clitics involved a considerable number of gender errors (see next section). These differences were observed until the age of 6 years, even though they decrease with age. As expected, the analyses of omissions showed the opposite profile, with many more omissions of the object clitic than the subject and reflexive clitics in young children ( $21 \%$ vs. $7.8 \%$ and $8.8 \%$, respectively), a difference that is observed until the age of 5 years. Substitutions of pronouns across pronominal categories were rare. Nevertheless, young children tended to produce more substitution errors on the object than on the reflexive clitic ("il se lave" or "il lui lave" instead of "il le lave"), further attesting to their difficulty with object clitics. The difference between object and subject omission in the 
youngest children is compatible with the "delay of object clitics" discussed in the literature (Hamann et al., 1996; Jakubowicz et al., 1997) and points to early difficulties with object clitics. Further, our observations suggest that reflexive clitics pattern with subject clitics, suggesting a possible structural similarity between the two.

In comprehension, children showed good performance in the truth-value judgment task. Performance on the match conditions (in which the sentence correctly depicted the photograph) was uniformly excellent at all ages tested and for all clitics. In conditions of binding mismatch, a small but systematic difference was found between Principle A and Principle B throughout the age range tested in this study. Children detected significantly more errors involving Principle A (error detection is already nearly perfect at $4 ; 0$ ) than errors involving Principle B (error detection varying from $87.5 \%$ at $4 ; 0$ to $93.8 \%$ at $6 ; 0$ ). This slightly worse performance with object pronouns than with reflexives in comprehension is at first sight reminiscent of the well-known "delay of Principle B effect" systematically found in the acquisition of the Germanic languages (Chien \& Wexler, 1990), but not in languages with clitics (Hamann et al., 1997). However, as the results supporting the delay of Principle B normally involve chance-level accuracy in Principle B environments ( $~ 50 \%$ in Chien \& Wexler, 1990), the high level of accuracy shown in our data $(>85 \%)$ confirms a sharp difference in the acquisition of languages with and without clitics. Still, the smaller but significant difference observed between object clitics and reflexives requires an explanation. To account for the finding that children show better performance with reflexive clitics than with object clitics not only in comprehension but also in production and, more generally, that reflexives pattern like subject clitics $(S=R>O)$, we appeal to a single formal property of chains. We argued in the introductory section that one factor singles out object clitics. The object clitic chain crosses the subject chain, whereas no crossing is involved in structures with subject and reflexive clitics. That no crossing is involved in subject chains unless there is an object clitic is obvious. Subjects are moved from the VP-internal position to their surface position without crossing any other nominal position in the general case. That reflexive clitic chains do not cross subject chains is less obvious but follows from Burzio's analysis (1986) described above. Thus, we argue that it is precisely the chain-crossing properties of object clitics that explains their slower acquisition in terms of the higher processing load required to process them.

Although the results presented here failed to show any difference between the processing of subject and reflexive clitics, some of the French literature suggests that the spontaneous production of reflexives may come later than subject clitics in typically developing children (Crysman \& Müller, 2000; Jakubowicz, 1989; Jakubowicz et al., 1998; Jakubowicz \& Rigaut, 2000) and in children with SLI (Cronel-Ohayon et al., 2010). Reflexives are headlike objects, in contrast to subjects that are full DPs. Hence, we cannot exclude that the other structural factor of complexity that was identified (head status) also plays a role in the acquisition of the pronominal system.

Finally, in line with previous studies on French, we found that the interpretation of object clitics is better (mean correct between $95.5 \%$ and $98.4 \%$, depending 
Zesiger et al.: Acquisition of French pronouns in children

on the age group for the match condition and between $87.5 \%$ and $93.8 \%$ for the mismatch condition without taking into account morphological errors; see Table 5) than their production (mean correct varying between $56.3 \%$ and $86.7 \%$, without taking into account morphological errors; see Table 3), which is characterized by massive omission. However, these two sets of data are not directly comparable. Whereas comprehension errors involved clitic substitutions, production errors involved clitic omissions.

A more direct comparison was recently provided by research by Gruter (2006) showing that children who typically omit clitics are actually sensitive to clitic omission in comprehension. Even though children tend to omit clitics in their productions, they were found to interpret a verb as transitive when presented with an object clitic but as intransitive when presented without the clitic. On this basis, Gruter suggested that object clitic omission by young children may reflect economy strategies at the level of the interface processes involved in language production (either presyntactic or postsyntactic, in the phonological encoding and/or articulatory planning) rather than at the level of syntax.

Nevertheless, it is important to note that even though interface or performance factors may play an important role in the occurrence of clitic omission in language production, they cannot explain by themselves the large difference reported between object and reflexive clitics. This difference seems to show the role of a specifically syntactic factor, which we identified as the crossing of subject and object chains in the derivation of object clitics.

The analysis of substitution errors produced by children in our study provides a more direct comparison to their performance in comprehension, because they consist in producing an object clitic in place of a reflexive clitic and vice versa, similarly to the mismatches introduced in the comprehension task. The overall rate of substitution errors in production $(3.1 \%$ of expected object clitics and $\sim 1 \%$ of expected reflexives in the younger group) is much closer to the rate of substitution errors in comprehension (8.5\% for object clitics and $0.8 \%$ for reflexive clitics in the younger group) than the omission rate. Moreover, the production of substitution errors shows the same difference between object clitics and reflexives as that observed in omission errors and comprehension errors.

In sum, omission errors, although much more massive than the other types of errors, show the same grammatical signature as substitution errors in production and as interpretative errors in comprehension. This signature manifests itself in terms of a higher error rate with object clitics than with reflexives, which we suggest arises as a consequence of the chain crossing involved in object clitics.

\section{Acquisition of the morphology of pronouns}

Young children showed major difficulties in processing pronoun gender. In production, children aged 4;0 produced nearly $30 \%$ gender errors on both subject and object clitics, and the error rate remains above $10 \%$ at age 6 . Of interest, gender errors were more common on feminine than masculine pronouns; that is, children tend to produce the masculine form in place of the feminine one. In comprehension, children of age 4 detected about half the gender errors on 
the object clitic, suggesting a performance at chance level. Their performance improves at age 6 , although they still only detect about $75 \%$ of the errors, showing that gender is still not systematically processed. This high error rate may be partially because the gender mismatch conditions did not include the possible referent of the pronoun in the picture. If the child did not remember the common ground of the whole experiment and the other recurring protagonists, this might have lead to infelicitous pronoun interpretation and thus an unexpected answer. However, the high error rate mirrors production. ${ }^{9}$ Moreover, as in production, an asymmetry is observed between masculine and feminine pronouns, which cannot be due to infelicitous pronoun interpretation: the feminine pronouns incorrectly used to refer to males on the photograph gave rise to better performance than masculine pronouns incorrectly referring to females. Our results are compatible with previous studies that examined the production of gender on pronouns and that reported a similar preference for the use of masculine pronouns in young French speakers (Clark, 1985; Jakubowicz, 1989; Jakubowicz \& Nash, in press).

The better performance reported with feminine pronouns in comprehension may at first glance seem inconsistent with the report of a higher error rate with feminine pronouns in production. However, it is coherent under the analysis of the feminine as the marked gender feature (e.g., Hulk \& Tellier, 1999). Whereas it is easier to produce an unmarked form (the masculine), an incorrect, marked form (the feminine), which is more salient, should be easier to detect in comprehension. A number of arguments favor the analysis of masculine as the default value. For example, it occurs with professions ( je vais chez le médecin "I'm going to the doctor") and generic nouns (le lion vit en Afrique "the lion lives in Africa"). The masculine pronoun is required to refer to conjunctions (les garcons et les filles arrivent. Ils sont en retard "the boys and the girls are back. They-M,P are late") and in constructions with expletive subjects (e.g., il est tard, "it is late"). The French database Lexique (New, Pallier, Ferrand, \& Matos, 2001) reflects the asymmety between masculine and feminine subject pronouns: the base contains 12,021 occurrences of $i l$ against 4,931 occurrences of elle. Unfortunately, it does not provide a distinction between the homophonous $l e$ and $l a$ as determiner or as object pronoun, but a similar default use of the masculine form applies to the object pronoun. Finally, experimental evidence from studies of gender agreement production in adults further supports the view that feminine forms are marked with respect to gender (e.g., Vigliocco \& Franck, 1999).

It is interesting to note that we find a similar asymmetry for number, with more number errors on plural targets $(7.3 \%)$ than on singular targets $(<1 \%)$, confirming findings for spontaneous production (Rasetti, 2003). The same explanation as for the gender asymmetry applies here, because the plural constitutes the marked number feature (Lapointe, 1986). Hence, for both gender and number errors, children tend to produce the default value (i.e., masculine) singular form of the pronoun (le) instead of the target (corroborating Franck et al., 2004).

Do our observations suggest that young children have not acquired gender as a morphosyntactic category of their language? Clear evidence against this view comes from the observation that gender is one of the first morphosyntactic features that appears on the article in French children's spontaneous speech, as early as age 2 (Kupisch et al., 2002). Moreover, experimental research shows that gender errors 
on determiners are rare in the productions of young children (for a recent study, see Jakubowicz \& Nash, in press). Unlike for the noun, gender is not an intrinsic property of the pronoun, and therefore has to be retrieved from the gender of the pronoun's antecedent or referent (via a process of agreement or concord). Hence, what seems to be at issue here is not the acquisition of gender as a property of the noun itself but the process by which the gender of the referent is copied onto the pronoun.

The poor performance with gender of the young children of our group, both in production and comprehension, stands in contrast with the observation that English-speaking children as early as age 2;6 use gender to disambiguate pronoun interpretation (Chien \& Wexler, 1990). English differs from Romance languages in that it does not have grammatical gender. This property of the gender system seems to have important developmental consequences. A number of studies conducted in languages with grammatical gender have illustrated that gender is acquired primarily as an abstract morphological feature, independent of biological sex (e.g., Levy, 1988). Karmiloff-Smith (1979) showed very clearly that in a situation of choice between morphophonological and semantic gender cues, young French-speaking children make use of the former rather than the latter, supporting the view that in early stages of language development gender is processed as a strictly grammatical feature, independent of its biological counterpart. In our truth-value judgment task, the only information available for gender selection on the pronoun was precisely the sex of the extralinguistic referent represented on the photograph (Mummy, Daddy, Diane, or Pierre). The absence of linguistic information as to the referent's gender may therefore have contributed to render gender processing more difficult, along the lines of the hypothesis that young French children have not encoded gender as a biological category but as a strictly grammatical/morphological feature of the noun.

The gender of the object pronoun in sentences involving the application of Principle B (Table 6) provides a potential cue to the processing of the pronoun. The mismatch between the object pronoun's gender and the sex of the local antecedent provides a cue to process binding, a cue that was found to help English-speaking children (Chien \& Wexler, 1990). Analyses of our data show a marginal effect in favor of the condition in which the gender of the pronoun is different from the sex of the antecedent but only in the 4;6 group (mean difference $=-10.0$ ), $t(19)=-2.027, p=.057$. In all other age groups, the difference between the two conditions is not significant (all $p s>.1$ ). Thus, gender does not appear to play a role in the processing of binding in French.

Why would English-speaking children behave differently? English does not have grammatical gender; however, it has developed means to represent biological sex in the language, in the form of what is commonly called semantic gender (Corbett, 1991). English pronouns referring to animate entities express the sex of their referent in their morphology (he/she, him/her, his/her). Thus, English differs from Romance languages in that semantic gender does not coexist with grammatical gender. In contrast to children from Romance languages who first acquire gender as a purely morphosyntactic feature (which later on will relate to biological sex), English children first acquire it as a semantic feature. The direct link between the pronoun's gender and the referent's biological sex in English 
would be responsible for the finding that the sex of the referent is processed as a cue to pronoun interpretation by English-speaking children, whereas it is not by French-speaking children for whom gender is not yet linked to biological sex in their immature lexicon.

\section{CONCLUSION}

This study showed that 4- to 6-year-old typically developing children generally master clitic placement and the distinction between different grammatical functions in the production and comprehension of the French system of pronominal clitics. We observed a delay in the acquisition of object clitics compared to that of reflexive clitics, both in production and in comprehension. Moreover, the production task revealed that reflexive clitics and subject clitics pattern alike. We argued that a major structural difference distinguishes object clitics from reflexive clitics, which may account for the delay reported with the former. Whereas the object chain crosses the subject chain, the reflexive chain is nested within the subject chain in the analysis adopted here. In line with previous reports in the literature (e.g., Fox \& Grodzinsky, 1998) chain crossing would be responsible for a higher structural complexity in the derivation of object clitics as compared to reflexive clitics, which would explain the delay reported in our data.

Moreover, our study revealed that French-speaking children have considerable difficulty with the gender of pronouns referring to persons. In production, nearly $30 \%$ of the subject and object pronouns produced by young children had an incorrect gender feature. In comprehension, gender mismatches with the sex of the referent were only detected in half of the sentences by young children. This observation is compatible with the view that semantic gender is acquired later than grammatical gender in Romance languages.

\section{APPENDIX A}

Stimuli used in the comprehension experiment

\begin{tabular}{ll}
\hline \hline \multicolumn{1}{c}{ Photograph } & \multicolumn{1}{c}{ Sentence } \\
\hline Pierre brosse Diane & Pierre la brosse \\
Pierre brosse Diane & Pierre le brosse \\
Pierre brosse Diane & Pierre se brosse \\
Maman brosse Pierre & Maman le brosse \\
Maman brosse Pierre & Maman la brosse \\
Maman brosse Pierre & Maman se brosse \\
Papa se brosse & Papa se brosse \\
Papa se brosse & Papa le brosse \\
Papa se brosse & Papa la brosse \\
Papa se brosse & Pierre se brosse \\
Diane brosse Pierre & Diane le brosse \\
Diane brosse Maman & Diane la brosse \\
Diane se brosse & Diane se brosse
\end{tabular}


Zesiger et al.: Acquisition of French pronouns in children

APPENDIX A (cont.)

\begin{tabular}{ll}
\hline \hline \multicolumn{1}{c}{ Photograph } & \multicolumn{1}{c}{ Sentence } \\
\hline Maman se brosse & Maman se brosse \\
Papa couvre Diane & Papa la couvre \\
Papa couvre Diane & Papa le couvre \\
Papa couvre Diane & Papa se couvre \\
Diane couvre Pierre & Diane le couvre \\
Diane couvre Pierre & Diane la couvre \\
Diane couvre Pierre & Diane se couvre \\
Pierre se couvre & Pierre se couvre \\
Pierre se couvre & Pierre le couvre \\
Pierre se couvre & Pierre la couvre \\
Pierre se couvre & Papa se couvre \\
Maman couvre Pierre & Maman le couvre \\
Maman couvre Diane & Maman la couvre \\
Maman se couvre & Maman se couvre \\
Diane se couvre & Diane se couvre \\
Maman mesure Diane & Maman la mesure \\
Maman mesure Diane & Maman le mesure \\
Maman mesure Diane & Maman se mesure \\
Pierre mesure Papa & Pierre le mesure \\
Pierre mesure Papa & Pierre la mesure \\
Pierre mesure Papa & Pierre se mesure \\
Diane se mesure & Diane se mesure \\
Diane se mesure & Diane la mesure \\
Diane se mesure & Diane le mesure \\
Diane se mesure & Maman se mesure \\
Papa mesure Pierre & Papa le mesure \\
Papa mesure Diane & Papa la mesure \\
Papa se mesure & Papa se mesure \\
Pierre se mesure & Pierre se mesure \\
Diane mouille Maman & Diane la mouille \\
Diane mouille Maman & Diane le mouille \\
Diane mouille Maman & Diane se mouille \\
Papa mouille Pierre & Papa le mouille \\
Papa mouille Pierre & Papa la mouille \\
Papa mouille Pierre & Papa se mouille \\
Maman se mouille & Maman se mouille \\
Maman se mouille & Maman la mouille \\
Maman se mouille & Maman le mouille \\
Maman se mouille & Diane se mouille \\
Pierre mouille Papa & Pierre le mouille \\
Pierre mouille Diane & Pierre la mouille \\
Pierre se mouille & Pierre se mouille \\
Papa se mouille & Papa se mouille \\
\hline \hline
\end{tabular}

Note: In all reflexive conditions (i.e., "Papa se brosse"), another person of the same gender is shown in the photograph in order to respect the felicity conditions. 
Zesiger et al.: Acquisition of French pronouns in children

\section{ACKNOWLEDGMENTS}

This work was part of a project on normal acquisition and SLI undertaken at the University of Geneva (Programme plurifacultaire, "Langage et Communication: Acquisition, Traitement et Pathologie"). We are very grateful to Olivier Renaud for his valuable help in statistical analyses and to the anonymous reviewers.

\section{NOTES}

1. The reason why object clitics, rather than subject clitics, would be selectively affected by the crossing of subject and object chains is that, although subject clitics move to subject position to satisfy the extended projection principle (like any other subject), object clitics move to a special, dedicated position. Hence, it is reasonable to assume that the crossing configuration may be avoided by blocking the special, item-specific instance of movement and leaving the general, arguably universal, movement to subject position unimpeded.

2. Other test cases may be provided by Scandinavian and Northern Italian dialects. Scandinavian object shift involves movement of a nonclitic object (full DP) to a VP external position across the thematic position of the subject (e.g., Jonas \& Bobalijk, 1993). Hence, if crossed subject-object chains constitute a sufficient condition for the delay of object clitics, one expects to find a similar delay in Scandinavian. In contrast, Northern Italian dialects have systems of subject clitics that differ from standard French in that they display headlike properties, while appearing in the canonical order SV, that is, without involving any chain crossing (e.g., Rizzi, 1986). Hence, if head status alone were responsible for the delay of object clitics, irrespective of crossed subjectobject chains, one would expect to find such a delay in Northern Italian dialects. Unfortunately, we are not aware of any study bearing on the acquisition of these constructions.

3. There is actually a third principle stating that a referring expression is always free.

4. See Elbourne (2005) and Conroy et al. (2010) for recent discussions of the experimental conditions in earlier work such as Chien and Wexler (1990) or Thornton and Wexler (1999). Both papers call into question the asymmetry observed in sentences with "name" antecedents and sentences with quantified antecedents.

5. One could also consider the possibility that simple linear order (canonical SV order for subject clitics, noncanonical OV order for object clitics) is a critical factor. However, in some Romance constructions object clitics are attached to the right of the verb, in enclitic position, for example, in French positive imperatives: prend-le; this yields canonical VO order, and still object enclitics do not seem to manifest themselves earlier than object proclitics (Clark, 1985; Hamann et al., 1996; Haverkort \& Weissenborn, 1991; Weissenborn, 1988). This suggests that an approach in terms of canonicity in linear ordering with respect to the verb is too coarse, and some more refined distinctive property like the chain configuration must be considered. The fact that alternations between canonical and noncanonical order are not problematic per se for the child is also suggested by the early mastery of OV-VO alternations in child German, as a function of verb second (Clahsen, 1991; Meisel, 1992; Verrips \& Weissenborn, 1992).

6. The statistical analyses performed with and without the five participants who were not fully monolingual lead to identical results.

7. Two features of this design are its use of the same material for production and comprehension and its simplicity, namely, the occurrence of only two protagonists in every 
Zesiger et al.: Acquisition of French pronouns in children

picture. This is unproblematic for most conditions but may violate felicity conditions in the case of the gender manipulations, (+syntax, binding b, - gender) and (-syntax, binding $b$, different gender) as one of the reviewers points out. The problem here is that the person of the different gender who could be a possible referent of the pronoun is not in the picture and was not mentioned in the lead-in. Because there were only four people mentioned in the experiment and the children were explicitly told that all the pictures and stories were about these four people and they had seen the same pictures before for production, we assumed that all four protagonists are part of the common ground during all the conditions. We will, however, consider the possibility of infelicitous pronoun use in connection with our results.

8. Logistic regression is a technique that is especially adapted for measures with dichotomous responses/results (e.g., success vs. failure or 1-0 scores). Dichotomous responses usually have extremely small variances for both high and low values of the independent variable (IV, e.g., age), whereas the variance is larger for median values of the IV where the scores 1 and 0 are about equally represented. This characteristic of dichotomous variables is problematic for the homogeneity and normality constraints of variance analyses (ANOVA/MANOVA). In contrast, logistic regression adjusts an $\mathrm{S}$ curve (sigmoid) to the observed data. Such an $\mathrm{S}$ curve has a slow progression within small values of $x$ (e.g., age), then a quicker progression within median values of $x$, and then again a slow progression within large values of $x$.

9. Note that in condition (-syntax, binding B, different gender) children were $90.3 \%$ to $96.1 \%$ accurate, which shows that infelicitous pronoun use is not problematic per se.

\section{REFERENCES}

Avrutin, S., \& Wexler, K. (1992). Development of Principle B in Russian: Coindexation at LF and coreference. Language Acquisition, 2, 259-306.

Baauw, S., \& Cuetos, F. (2003). The interpretation of pronouns in Spanish language acquisition and breakdown: Evidence for the "Principle B Delay" as a non-unitary phenomenon. Language Acquisition, 11, 219-275.

Bates, E., \& Devescovi, A. (1989). Cross-linguistic studies of sentence production. In B. MacWhinney $\&$ E. Bates (Eds.), The cross-linguistic study of sentence processing (pp. 225-253). Cambridge: Cambridge University Press.

Bishop, D. V. M. (1983). The Test for Reception of Grammar. Manchester: University of Manchester, Age and Cognitive Performance Research Centre.

Bloom, P. (1990). Subjectless sentences in child language. Linguistic Inquiry, 21, 491-504.

Bloom, P., Baars, A., Conway, L., \& Nicol, J. (1994). Children's knowledge of binding and coreference. Evidence from spontaneous speech. Language, 70, 53-71.

Bottari, P., Cipriani, P., \& Chilosi, A. M. (1997). Dissociations in the acquisition of clitic pronouns in dysphasic children: A case study from Italian. Paper presented at the Conference on Syntax, Morphology and Phonology in Specific Language Impairment, Paris.

Burzio, L. (1986). Italian syntax. Dordrecht: Reiledd.

Cardinaletti, A., \& Starke, M. (1999). The typology of structural deficiency: A case study of the three classes of pronouns. In H. v. Riemsdijk (Ed.), Clitics in the languages of Europe. Berlin: Mouton de Gruyter.

Chien, Y.-C., \& Wexler, K. (1990). Children's knowledge of locality conditions in binding as evidence for the modularity of syntax and pragmatics. Language Acquisition, 1, 225-295.

Chillier, L., Arabatzi, M., Baranzini, L., Cronel-Ohayon, S., Deonna, T., Dubé, S., et al. (2001). The acquisition of French pronouns in normal children and in children with specific language impairment (SLI). Paper presented at Early Lexicon Acquisition (ELA), Lyon [CD].

Chomsky, N. (1981). Lectures in government and binding. Dordrecht: Foris Publications. 
Zesiger et al.: Acquisition of French pronouns in children

Clahsen, H. (1991). Constraints on parameter setting. Language Acquisition, 1, 361-391.

Clark, E. (1985). The acquisition of Romance with special reference to French. In D. I. Slobin (Ed.), The cross-linguistic study of language acquisition. Mahwah, NJ: Erlbaum.

Cocchi, G. (1995). La selezione dell'ausiliare. Padua, Italy: Unipress.

Conroy, A., Takahashi, E., Lidz, J., \& Phillips, C. (2010). Equal treatment for all antecedents: How children succeed with Principle B. Manuscript submitted for publication.

Coopmans, P., \& Philip, W. (1995, April). The role of lexical feature acquisition in the development of pronominal anaphora. Paper presented at the Child Language Seminar, Bristol.

Corbett, G. G. (1991). Gender. Cambridge: Cambridge University Press.

Cronel-Ohayon, S., Chillier, L., Arabatzi, M., Frauenfelder, U. H., Hamann, C., Zesiger, P., et al. (2010). Production and comprehension of pronominal clitics in French SLI. Unpublished manuscript.

Crysmann, B., \& Müller, N. (2000). On the non-parallelism in the acquisition of reflexive and nonreflexive object clitics. In S. Powers \& C. Hamann (Eds.), The acquisition of scrambling and cliticization. Dordrecht: Kluwer.

De Cat, C. (2005). French subject clitics are not agreement markers. Lingua, 108, 1195-1219.

Elbourne, P. (2005). On the acquisition of Principle B. Linguistic Inquiry, 36, 333-365.

Fox, D., \& Grodzinsky, Y. (1998). Children's passive: A view from the by-phrase. Linguistic Inquiry, $29,311-332$.

Franck, J., Cronel-Ohayon, S., Chillier, L., Frauenfelder, U. H., Hamann, C., Rizzi, L., et al. (2004). Normal and pathological development of subject-verb agreement in speech production: A study on French children. Journal of Neurolinguistics, 17, 147-180.

Friedemann, M. A. (1992). The underlying position of external arguments in French. Geneva Generative Papers, 2, 123-144.

Gruter, T. (2006). Object clitics and null objects in the acquisition of French. Unpublished doctoral dissertation, McGill University.

Hamann, C. (2002). From syntax to discourse: Pronominal clitics, null subjects and infinitives in child language. Dordrecht: Kluwer.

Hamann, C., Cronel-Ohayon, S., Dubé, S., Frauenfelder, U., Rizzi, L., Starke, M., et al. (2003). Aspects of grammatical development in young French children with SLI. Developmental Science, 6, $153-160$.

Hamann, C., Kowalski, O., \& Philip, W. (1997). The French "delay of Principle B" effect. In E. Hughes, M. Hughes, \& A. Greenhill (Eds.), Proceedings of the 21st Annual Boston University Conference on Language Development (Vol. 21, pp. 205-219). Somerville, MA: Cascadilla Press.

Hamann, C., Rizzi, L., \& Frauenfelder, U. H. (1996). On the acquisition of subject and object clitics in French. In H. Clahsen (Ed.), Generative perspectives on language acquisition. Philadelphia, PA: John Benjamins.

Haverkort, M., \& Weissenborn, J. (1991). Clitic and affix interaction in early Romance. Paper presented at the 16th Boston University Conference on Language Development (BUCLD), Boston.

Hulk, A., \& Tellier, C. (1999). Conflictual agreement in Romance nominals. In J. M. Authier, B. Bullock, \& L. Reed (Eds.), Formal perspectives in Romance clitics (pp. 179-195). Amsterdam: Benjamins.

Hyams, N., \& Wexler, K. (1993). On the grammatical basis for null subjects in child language. Linguistic Inquiry, 24, 421-459.

Jakubowicz, C. (1989). Maturation or invariance of universal grammar principles in language acquisition. Probus, 3, 283-340.

Jakubowicz, C., Müller, N., Riemer, B., \& Rigaut, C. (1997). The case of subject and object omission in French and German. In E. Hughes, M. Hughes, \& A. Greenhill (Eds.), Proceedings of the 21 st Annual Boston University Conference on Language Development (Vol. 21, pp. 331-342). Somerville, MA: Cascadilla Press.

Jakubowicz, C., \& Nash, L. (in press). Why accusative clitics are avoided in normal and impaired language development. In C. Jakubowicz, L. Nash, \& K. Wexler (Eds.), Essays in syntax, morpholoy and phonology in SLI. Cambridge, MA: MIT Press.

Jakubowicz, C., Nash, L., Rigaut, C., \& Gérard, C.-L. (1998). Determiners and clitic pronouns in French-speaking children with SLI. Language Acquisition, 7, 113-160. 
Zesiger et al.: Acquisition of French pronouns in children

Jakubowicz, C., \& Rigaut, C. (2000). L'acquisition des clitiques nominatifs et des clitiques objets en Français. Canadian Journal of Linguistics, 45, 119-157.

Jonas, D., \& Bobalijk, J. (1993). Specs for subjects: The role of TP in Icelandic. MIT Working Papers in Linguistics, 18, 59-98.

Kail, M. (1989). Cue validity, cue cost and processing types in sentence comprehension in French and Spanish. In B. MacWhinney \& E. Bates (Eds.), The cross-linguistic study of sentence processing (pp. 77-117). Cambridge: Cambridge University Press.

Kail, M., \& Léveillé, M. (1977). Compréhension de la coréférence des pronoms personnels chez l'enfant et chez l'adulte. L'Année Psychologique, 77, 79-94.

Karmiloff-Smith, A. (1979). A functional approach to child language. Cambridge: Cambridge University Press.

Kayne, R. (1975). French syntax. Cambridge, MA: MIT Press.

Koster, J. (1993). Towards a new theory of anaphoric binding. Unpublished doctoral dissertation, University of Groningen.

Kupisch, T., Müller, N., \& Cantone, K. (2002). Gender in French and Italian. Lingue e Linguaggio, 1, 107-149.

Lapointe, S. G. (1986). Markedness, the organisation of linguistic information in speech production, and language acquisition. In F. R. Eckman, E. A. Moravcsik, \& J. R. Wirth (Eds.), Markedness (pp. 219-239). New York: Plenum Press.

Lecocq, P. (1996). L'E.CO.S.SE: Une épreuve de compréhension syntaxico-sémantique. Villeneuve d'Ascq, France: Presses Universitaires du Septentrion.

Levy, Y. (1988). On the early learning of formal grammatical systems: Evidence from studies of the acquisition of gender and countability. Journal of Child Language, 15, 179-187.

McDaniel, D., \& Maxfield, T.-L. (1992). Principle B and contrastive stress. Language Acquisition, 2, 337-358.

McKee, C. (1992). A comparison of pronouns and anaphors in Italian and English acquisition. Language Acquisition, 2, 21-54.

Meisel, J. (1992). The acquisition of verb placement. Functional categories and V2 phenomena in language acquisition. Dordrecht: Kluwer.

New, B., Pallier, C., Ferrand, L., \& Matos, R. (2001). Une base de données lexicales du Français contemporain sur internet: LEXIQUE. L'Année Psychologique, 101, 447-462.

Paradis, J., Crago, M., \& Genesee, F. (2003). Object clitics as a clinical marker of SLI children in French: Evidence from French-English bilingual children. In B. Beachley, A. Brown, \& F. Conlin (Eds.), Proceedings of the 27th Annual Boston University Conference on Language Development (Vol. 27, pp. 638-649). Somerville, MA: Cascadilla Press.

Piérart, B., Comblain, A., Gregoire, J., Mousty, P., \& Noël, M.-P. (2010). Isadyle: A battery of language tests. Unpublished manuscript.

Pierce, A. (1992). Language acquisition and syntactic theory. Dordrecht: Kluwer.

Rasetti, L. (2003). Optional categories in early French syntax: A developmental study of root infinitives and null arguments. Unpublished doctoral dissertation, University of Geneva.

Reinhart, T. (2004). Processing or pragmatics? Explaining the coreference delay. In T. Gibson \& N. Perlmutter (Eds.), The processing and acquisition of reference. Cambridge, MA: MIT Press.

Reuland, E. (2001). Primitives of binding. Linguistic Inquiry, 32, 439-492.

Rizzi, L. (1986). On the status of subject clitics in Romance. In O. Jaeggli \& C. Silva-Corvalan (Eds.), Studies in Romance linguistics. Dordrecht: Foris.

Rondal, J.-A., Espéret, E., Gombert, J. E., Thibaut, J.-P., \& Comblain, A. (1999). Développement du langage oral. In J.-A. Rondal \& X. Seron (Eds.), Troubles du langage: Bases théoriques, diagnostic et rééducation. Liège, Belgium: Mardaga.

Schall, R. (1991). Estimation in generalized linear models with random effects. Biometrika, 78, 719 727.

Sigurjónsdóttir, S., \& Hyams, N. (1992). Reflexivization and logophoricity: Evidence from the acquisition of Icelandic. Language Acquisition, 2, 359-413.

Sportiche, D. (1998). Partitions and atoms of clause structure. subjects, agreement, case and clitics. London: Routledge.

Thornton, R., \& Wexler, K. (1999). Principle B, VP ellipsis, and interpretation in child grammar. Cambridge, MA: MIT Press. 
Zesiger et al.: Acquisition of French pronouns in children

Verrips, M., \& Weissenborn, J. (1992). Routes to verb placement in German and French. In J. Meisel (Ed.), The acquisition of verb placement. Functional categories and V2 phenomena in language acquisition. Dordrecht: Kluwer.

Vigliocco, G., \& Franck, J. (1999). When sex and syntax go hand in hand: Gender agreement in language production. Journal of Memory and Language, 40, 455-478.

Weissenborn, J. (1988). The acquisition of clitic object pronouns and word order in French: Syntax or morphology? Paper presented at the 3rd International Morphology Meeting, Krems, Austria.

White, L. (1996). Clitics in L2-French. In H. Clahsen (Ed.), Generative perspectives on language acquisition. Philadelphia, PA: John Benjamins.

Zribi-Hertz, A. (1994). Les clitiques nominatifs en Français: Syntaxe, pédagogie et variation. Doctoral dissertation, University of Paris. 